\title{
A novel chiral manganese-tetraamide macrocycle complex covalently attached to magnetite as recyclable catalyst for aerobic asymmetric epoxidation of olefins
}

\author{
Leila Hadian-Dehkordi ${ }^{\mathrm{a}}$, Hassan Hosseini-Monfared ${ }^{\mathrm{a},{ }^{*}}$, Pavlo Aleshkevych ${ }^{\mathrm{b}}$ \\ ${ }^{a}$ Department of Chemistry, University of Zanjan 45195-313, Zanjan, Islamic Republic of Iran. \\ Email: monfared@znu.ac.ir \\ ${ }^{b}$ Institute of Physics, Polish Academy of Sciences (PAN), Al. Lotnikow 32/46, PL-02-668 \\ Warsaw, Poland. Email: pavloa@ifpan.edu.pl
}

\begin{abstract}
A novel Mn complex containing $\mathrm{N}_{4}$-tetradentate tetraamide macrocyclic ligand (L) derived from chiral diethyl-2,3-benzylidene-L-tartrate and polyamidoamine dendrimer on $\mathrm{Fe}_{3} \mathrm{O}_{4} @ \mathrm{SiO}_{2}$ surface was synthesized. The nanocomposite particles were investigated by SEM, XRD, VSM, EPR and FTIR. The nanocomposite showed high catalytic activity and selectivity for the epoxidation of linear terminal, cyclic and most of the aromatic olefins by $\mathrm{O}_{2}$ in the presence of isobutyraldehyde under mild conditions; epoxide selectivity $87-100 \%$, enantiomeric excess 53 $100 \%$. The catalyst could be separated and recovered from the reaction system by applying an

\footnotetext{
* Corresponding author. Tel.: +98 24 33052576; fax: +98 24 33283203. E-mail address: monfared@znu.ac.ir (H. Hosseini-Monfared).
} 
external magnetic field and reused for four cycles without the loss of activity after each cycle. Total TON of 16957 was obtained after four cycles.

Keywords: Nanocomposite; Mn(III) complex; Magnetite; Enantioselective epoxidation; Tetraamide macrocyclic ligand

\section{Introduction}

Catalytic asymmetric epoxidation of olefins is a very important organic transformation since the resulting enantiomerically pure epoxides are highly useful intermediates and building blocks $[1,2]$. Numerous asymmetric catalysts have been designed for producing enantioenriched compounds in the past four decades $[3,4,5]$ and the main emphasis has been on catalyst design to get the targeted epoxide with high enantioselectivity and yield [1]. Metal complexes of first row transition elements, such as manganese and iron being less toxic [6] and biologically abundant [7], are ideal when developing „,green ${ }^{\text {ceee }}$ catalysts. Among existing catalytic approaches, manganese is particularly attractive candidate in account of its cost and natural abundance (the 3rd transition metal in the earth crust after iron and titanium) and biocompatibility, which is

particularly valuable for the pharmaceutical industry [8]. The potential of manganese is seen in a number of biochemical redox processes such as peroxidases [9], catalases [10] and in photosystem II (PSII) [11] where it is involved in the oxidation of water to dioxygen [12].

Macrocyclic ligands are considerably attractive in the quest for new chemistry, because they offer a wide variety of donor atoms, ionic charges, coordination numbers and geometry of the resultant complexes $[13,14]$. In addition, they impart thermodynamic and kinetic stabilities to their metal complexes uncommon or non-existent with ligands of lesser types. Macrocyclic 
chelators can form highly stable complexes with transition metals and lanthanides and the complexes of macrocyclic ligands are used in imaging as MRI contrast agents, radiopharmaceuticals and luminescent probes [15]. Macrocyclic ligand complexes are of great importance in a number of biological processes such as photosynthesis and dioxygen transport [16]. Many metal complexes of naturally occurring porphyrins, corrins and phthalocyanines macrocycles have been investigated because of their potential as dyestuffs or pigments [17]. Several contributions have been made regarding the oxidation with macrocyclic ligand complexes. Manganese meso-tetraaryl porphyrins have been studied intensively as catalysts for epoxidation of olefins [18]. Tetrapyrrolic macrocycles (namely porphyrins and phthalocyanines) supported on micro and mesoporous inorganic supports have been used as oxidation catalysts [19]. Manganese complexes with polydentate N-donor ligands catalyze olefin epoxidations with percarboxylic acids or $\mathrm{H}_{2} \mathrm{O}_{2}$ in a chemo- and sometimes enantioselective fashion with high efficiency [20]. Nevertheless, these $\mathrm{N}_{4}$ ligands have shown very interesting results in asymmetric epoxidation of olefins with ee up to $96 \%$ with selected substrates, but mostly at temperatures of $-20{ }^{\circ} \mathrm{C}$ or below. Moreover, the synthetic protocols of these ligands are tedious, multi-step and often require expensive chiral starting materials. Metal(III) complex of a biuret-amide based macrocyclic ligand exhibits both excellent reactivity for the activation of $\mathrm{H}_{2} \mathrm{O}_{2}$ and high stability at low $\mathrm{pH}$ and high ionic strength [21]. Maity et al. reported manganese complexes with nonporphyrin $\mathrm{N}_{4}$ ligands as recyclable catalyst for the asymmetric epoxidation of olefins [22]. One class of these macrocycles is those incorporating amide groups. The amide groups can bind with different metal ions via nitrogen and/or oxygen atoms [23]. Also, macrocyclic amides are ubiquitous in biochemistry, because they provide the linkages that held together two of the most important types of biopolymers, nucleic acids and proteins [24]. Collins et al. have developed 
robust tetraamido macrocyclic ligands (TAMLs) for iron for water oxidation [25]. They used very strongly donor deprotonated amide ligands to allow access to high oxidation state iron and resulting in a series of extremely robust macrocycles.

On the other side, the soluble catalysts suffer from problems associated with the instability, separation and recovery of the expensive catalyst. Immobilization of catalysts on solid supports allows easy separation from the reaction mixture by simple filtration and thus greatly facilitates the handling of such catalysts. Using magnetic nanoparticles as support for immobilization of catalytically active species presents the opportunity to solve a range of catalyst recovery and diffusion of substrates problems [26]. As prepared nanocomposite nanoparticles act under favorable quasi-homogeneous conditions and can be recycled by simple magnetic decantation rather than time-consuming and energy-intensive filtration or centrifugation [27]. Magnetically recoverable nanocatalysts have been used in organic synthesis for a wide range of catalytic reactions $[28,29]$.

It is believed that substantial room for improvement remains in terms of catalyst cost and use of environmentally friendly oxidants with high atom efficiency. With this backdrop, we have come up with a simple methodology to synthesize a chiral tetraamide $\mathrm{N}_{4}$ ligand (L) immobilized on $\mathrm{Fe}_{3} \mathrm{O}_{4} @ \mathrm{SiO}_{2}$ with readily available chiral diethyl-L-(+)-tartrate, ethylene diamine, methyl acrylate as starting materials in three convenient steps. We then used its manganese complex in the asymmetric epoxidation of olefins with $\mathrm{O}_{2}$ as environmentally friendly oxidant with high atom efficiency at room temperature.

\section{Experimental}

\subsection{Materials and instrumentation}


L-(+)-Tartaric acid (>99\%, Merck), iron(III) chloride hexahydrate (98\%, Fluka), diethylene glycol (99\%, Merck), manganese(II) chloride tetrahydrate (>99\%, Merck), methyl acrylate (>99\%, Merck), (3-aminopropyl)triethoxysilane (Fluka, 98\%), ammonia (25\%, Mojallali, Iran), tetraethoxysilane (99\%, Merck), polyvinylpirolidone (PVP) (Mr 55,000 Da, Merck), cyclohexene (99\%, Fluka), 1-methyl-1-cyclohexene (97\%, Sigma-Aldrich), alpha-methyl styrene ( $>99 \%$, Merck), cis-stilbene (>95\%, Merck), trans-stilbene (96\%, Sigma) and other reagents were obtained from commercial sources and used as received without further purification. $(+)-$ Diethyl-L-tartrate and diethyl-2,3-O-benzylidene-L-tartrate were prepared from L-(+)-tartaric acid following previously reported procedure [30]. $\mathrm{Fe}_{3} \mathrm{O}_{4} /$ tart-NPs $(\mathrm{MNs})$ were prepared according to our reported procedure [31].

The reaction products of the oxidation were determined and analyzed by HP Agilent 6890 gas chromatograph equipped with flame-ionization detector. The enantiomeric excess (ee\%) was obtained by chiral GC column. To determine the conversion an HP-5 capillary column (phenyl methyl siloxane $30 \mathrm{~m} \times 320 \mu \mathrm{m} \times 0.25 \mu \mathrm{m})$ was used. The carrier gas $\left(\mathrm{N}_{2}\right)$ flow rate was 0.7 $\mathrm{mL} / \mathrm{min}$. The column was held at $90{ }^{\circ} \mathrm{C}$ for $0.1 \mathrm{~min}$, ramped at $10{ }^{\circ} \mathrm{C} / \mathrm{min}$ to $190^{\circ} \mathrm{C}$, and then held $20 \mathrm{~min}$ at this temperature, before the temperature program was stopped. The enantiomeric excess (ee\%) was determined using a SGE-CYDEX-B capillary column $(25 \mathrm{~m} \times 0.22 \mathrm{~mm}$ ID $\times$ $0.25 \mu \mathrm{m})$. The carrier gas $\left(\mathrm{N}_{2}\right)$ flow rate was $0.7 \mathrm{~mL} / \mathrm{min}$. The oven temperature was held at 50 ${ }^{\circ} \mathrm{C}$ for $0.10 \mathrm{~min}$, then heated to $150^{\circ} \mathrm{C}$ at a rate of $10{ }^{\circ} \mathrm{C} \mathrm{min}-1$ and kept for $15 \mathrm{~min}$. Then the temperature program was stopped. ${ }^{1} \mathrm{H}$ - and ${ }^{13} \mathrm{C}-\mathrm{NMR}$ spectra of the reaction mixture (without purification) were recorded on a Bruker $250 \mathrm{MHz}$ spectrometer. Fourier transform infrared (FTIR) spectra were run using a Perkin-Elmer 597 spectrophotometer after making pellets with $\mathrm{KBr}$ powder. Powder X-ray diffraction patterns were collected at the X'Pert Pro, Herzog, Germany, 
wavelength $1.5419 \AA(\mathrm{Cu} \mathrm{K} \alpha)$, voltage: $40 \mathrm{kV}$, current, $40 \mathrm{~mA}$. The size and morphology of solid compounds were recorded by using a Hitachi F4160 scanning electron microscope (SEM) operated at an accelerating voltage of $10 \mathrm{KV}$. Magnetization measurement was performed at room temperature using a vibrating sample magnetometer (VSM) device in the Development Center of the University of Kashan (Kashan, Iran). EPR measurements were carried out using a Bruker EMX spectrometer working at a fixed frequency of $9.38 \mathrm{GHz}$ (X-band) with an Oxford Instruments helium-flow cryostat.

\subsection{Synthesis of silica coated magnetite, $\mathrm{Fe}_{3} \mathrm{O}_{4} @ \mathrm{SiO}_{2}$}

Similar to reported procedure [32], $\mathrm{Fe}_{3} \mathrm{O}_{4} /$ tart-NPs solution $\left(34 \mathrm{~mL}, 20 \mathrm{mg} \mathrm{MNs} \mathrm{mL}^{-1}\right.$ solution in deionized water) was added to PVP solution $\left(0.64 \mathrm{~mL}, 25.6 \mathrm{gL}^{-1}\right.$ in deionized water) and the mixture stirred for 1 day at room temperature. The PVP-stabilized nanoparticles were separated by addition of aqueous acetone $\left(\mathrm{H}_{2} \mathrm{O} /\right.$ acetone $\left.=1 / 10, \mathrm{v} / \mathrm{v}\right)$ and centrifugation at $4000 \mathrm{rpm}$ for 10 min. The PVP-coated magnetite nanoparticles was suspended in $50 \mathrm{~mL}$ of 2-propanol containing $34 \mathrm{~mL}$ of concentrated ammonia (25\%) [33] and sonicated for $1 \mathrm{~h}$. After that, $3.4 \mathrm{~mL}(15.2$ mmol) of tetraethoxysilane (TEOS) in $40 \mathrm{~mL}$ of 2-propanol were added dropwise within $3 \mathrm{~h}$ to the magnetite suspension while it was stirring with a mechanical stirrer. The stirring was continued for another $3 \mathrm{~h}$, and then the silica-coated nanoparticles were separated magnetically, washed five times with DI water and dried at room temperature $(1.37 \mathrm{~g})$.

\subsection{Amine functionalization of $\mathrm{Fe}_{3} \mathrm{O}_{4} @ \mathrm{SiO}_{2}\left(\mathrm{Fe}_{3} \mathrm{O}_{4}-\mathrm{NH}_{2}\right)$}


$1.28 \mathrm{~g}$ of dry silica-coated magnetite powder was suspended in $26 \mathrm{~mL}$ of dry toluene. After sonication for $35 \mathrm{~min}$, (3-aminopropyl)triethoxysilane (APTES) $(1.37 \mathrm{mmol})$ was added under mechanical stirring. The solution was heated at $105^{\circ} \mathrm{C}$ for $20 \mathrm{~h}$. The particles were separated by an external magnet after cooling to room temperature, washed three times with dry methanol and dried at room temperature $(1.24 \mathrm{~g})$.

\subsection{Synthesis of $\mathrm{Fe}_{3} \mathrm{O}_{4}$-polyamidoamine dendrimer $\left(\mathrm{Fe}_{3} \mathrm{O}_{4}\right.$-en)}

$1.14 \mathrm{~g}$ of amine functionalized nanoparticles $\left(\mathrm{Fe}_{3} \mathrm{O}_{4}-\mathrm{NH}_{2}\right)$ were suspended in $17 \mathrm{~mL}$ methanol and sonicated for $35 \mathrm{~min}$. After that, $1.4 \mathrm{~mL}$ methyl acrylate $(15.4 \mathrm{mmol})$ was added and the mixture heated at $50{ }^{\circ} \mathrm{C}$ for 5 days. The resulting mixture was cooled to room temperature, the particles separated magnetically, washed three times with methanol and dried at room temperature. As a result $1.04 \mathrm{~g}$ brown powder of $\mathrm{Fe}_{3} \mathrm{O}_{4}-\mathrm{COOMe}$ was obtained. Dried $\mathrm{Fe}_{3} \mathrm{O}_{4}{ }^{-}$ COOMe $(0.94 \mathrm{~g})$ was then suspended again in $14 \mathrm{~mL}$ of methanol and sonicated for $30 \mathrm{~min}$. After dropwise addition of $2.0 \mathrm{~mL}(30.18 \mathrm{mmol})$ ethylenediamine at room temperature, the solution was heated at $50{ }^{\circ} \mathrm{C}$ for 5 days. The magnetic material was magnetically separated, washed 3 times with dry methanol, and dried at room temperature. As synthesized $\mathrm{Fe}_{3} \mathrm{O}_{4-}$ polyamidoamine dendrimer $\left(\mathrm{Fe}_{3} \mathrm{O}_{4}\right.$-en) weight was $0.94 \mathrm{~g}$ [33].

\subsection{Synthesis of $\mathrm{Fe}_{3} \mathrm{O}_{4}-[\mathrm{MnCl}(\mathrm{L})]$ ( $\mathrm{L}=$ a chiral tetraamide macrocyclic ligand)}


The prepared $\mathrm{Fe}_{3} \mathrm{O}_{4}$-en (0.405 g) was stirred with 4.55 mmol (1.34 g) of diethyl-2,3-Obenzylidene-L-tartrate in $10 \mathrm{ml}$ of ethanol for 5 days at room temperature [34] to give a chiral macrocycle anchored onto magnetite $\left(\mathrm{Fe}_{3} \mathrm{O}_{4}-\mathrm{L}\right.$, Scheme 1) (0.26 g).

The immobilized $\left[\mathrm{Mn}^{\mathrm{III}} \mathrm{Cl}(\mathrm{L})\right]$ was prepared by refluxing as prepared $\mathrm{Fe}_{3} \mathrm{O}_{4}-\mathrm{L}(0.26 \mathrm{~g})$ with $\mathrm{MnCl}_{2} \cdot 4 \mathrm{H}_{2} \mathrm{O}(1.31 \mathrm{~g}, 6.60 \mathrm{mmol})$ in dried toluene for $14 \mathrm{~h}$. The resulting solid was magnetically filtered and washed three times with $\mathrm{MeOH}$. The recovered powder was extracted in a Soxhlet using refluxing $\mathrm{MeOH}(750 \mathrm{~mL})$ for $24 \mathrm{~h} \mathrm{[35].}$

\subsection{Oxidation of olefins}

The oxidation of olefins was performed in a $25-\mathrm{mL}$ round-bottom flask equipped with a small magnetic bar. In a typical experiment the flask was charged with the suspension of $2.0 \mathrm{mmol}$ substrate, $1.0 \mathrm{mg} \mathrm{Fe}_{3} \mathrm{O}_{4}-[\mathrm{MnCl}(\mathrm{L})]$ nanocomposite (contains $0.46 \mathrm{mmol} \mathrm{Mn} / \mathrm{g}$ composite), 5.0 mmol isobutyraldehyde and $3 \mathrm{~mL}$ acetonitrile as solvent. The reaction was performed under oxygen atmosphere by using $\mathrm{O}_{2}$ balloon. At the end of $8 \mathrm{~h}$, the catalyst was removed by an external magnet $(1.2 \mathrm{~T})$ and the product mixture analyzed by gas chromatography. Conversions and yields were calculated with respect to the starting substrate. The reaction products were quantified by gas chromatography and identified by comparison with the retention time and spectral data to those of an authentic sample. To ensure reproducibility each catalytic reaction was carried out at least two times.

For recycling experiments, after completion of the reaction, the nanocatalyst was recovered using a magnet, washed with acetonitrile, dried at $80^{\circ} \mathrm{C}$ for $1 \mathrm{~h}$ and reused.

\subsection{Proof of stereochemistry}


Prochiral olefins were oxidized by $\mathrm{Fe}_{3} \mathrm{O}_{4}-[\mathrm{MnCl}(\mathrm{L})]$ and $\mathrm{RCHO} / \mathrm{O}_{2}$. Analysis of the corresponding chiral products by chiral GC was used to determine the enantioselectivity of the reaction. The absolute configuration was established by comparing the GC data with those observed for R-(+)-limonene.

\section{Results and discussion}

\subsection{Synthesis and characterization}

Magnetite nanoparticles $\left(\mathrm{Fe}_{3} \mathrm{O}_{4} /\right.$ tart-NPs $)$ with an average size of $14.1 \mathrm{~nm}$ synthesized in diethylene glycol in the presence of L-(+)-tartaric acid $\left(\mathrm{Fe}_{3} \mathrm{O}_{4} / \operatorname{tart}\right)$ (Eq. 1) [31], were stabilized with PVP to make them homogeneously dispersed in 2-propanol. The nanoparticles were coated with a shell of stable silica $\left(\mathrm{SiO}_{2}\right)$. The PVP method has been applied to magnetite nanoparticles having ionic surface charges to generate a sol-gel silica coating with TEOS [36].

$$
\mathrm{FeCl}_{3} 6 \mathrm{H}_{2} \mathrm{O}+\text { Diethylene glycol }+ \text { Urea } \underset{200^{\circ} \mathrm{C}, 4 \mathrm{~h}}{\stackrel{\mathrm{L}-(+) \text {-tartaric acid }}{\longrightarrow}} \mathrm{Fe}_{3} \mathrm{O}_{4} / \text { tart-NPs }
$$

The crystallinity and magnetic properties of the core material did not change upon coating with silica. Fig. 1 shows the representative XRD pattern of $\mathrm{Fe}_{3} \mathrm{O}_{4}$-NPs synthesized in the presence of tartaric acid. The intense peak at $2 \theta=35.87, \mathrm{FWH}=0.413$, demonstrates the crystallite size of $20.2 \mathrm{~nm}$ by Xert program. The sharp and intense peaks indicate the good crystallinity of the sample. The diffraction peaks can be well corresponded to the standard magnetite $\mathrm{Fe}_{3} \mathrm{O}_{4}$ (Ref. code 01-075-0449). Comparison of the patterns of $\mathrm{Fe}_{3} \mathrm{O}_{4} /$ tart and $\mathrm{Fe}_{3} \mathrm{O}_{4^{-}}$ $[\mathrm{MnCl}(\mathrm{L})]$ shows the amorphous silica coating of the magnetite in $\mathrm{Fe}_{3} \mathrm{O}_{4}-[\mathrm{MnCl}(\mathrm{L})]$ composite as a broad peak about $2 \theta=23^{\circ}$. 
$<$ Fig. $1>$

Enantiomerically pure (+)-diethyl-L-tartrate was synthesized by treatment of L-(+)tartaric acid with ethanol, and then its dihydroxyl groups protected by benzaldehyde in the presence of $p$-toluenesulfonic acid to produce diethyl-2,3-benzylidene-L-tartrate in high yield (Eq. 2) [30].

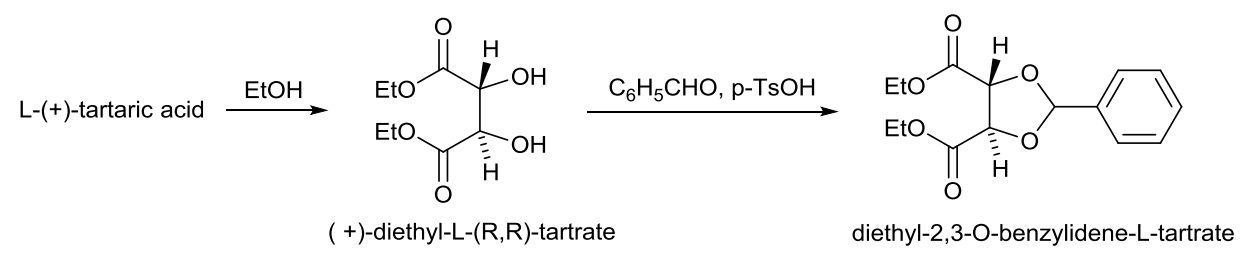

Polyaminoamido dendrimer was constructed on the surface of magnetite nanoparticles. The introduction of amino groups onto the magnetite surface for the preparation of an initiator site was achieved by the treatment of $\mathrm{Fe}_{3} \mathrm{O}_{4} @ \mathrm{SiO}_{2}$ surface silanol groups with APTES. The amino propionate ester $\left(\mathrm{Fe}_{3} \mathrm{O}_{4}-\mathrm{CO}_{2} \mathrm{Me}\right)$ was formed by a Michael-type addition of the magnetite immobilized aminopropyl $\left(\mathrm{Fe}_{3} \mathrm{O}_{4}-\mathrm{NH}_{2}\right)$ amino group to methyl acrylate. Subsequent amidation of the ester moiety with ethylenediamine completed the first generation of polyaminoamido dendrimer $\left(\mathrm{Fe}_{3} \mathrm{O}_{4}\right.$-en). Dendrimers are highly branched macromolecules and are of great interest as carriers of functional groups [37]. Consequently, dendritic catalysts have found numerous applications including metal complexation and occasional use as catalysts [38]. Dendrimer building methods pioneered by Tsubokawa and co-workers [39] were employed to propagate the dendrimer generation.

The chiral tetraamide macrocyclic ligand anchored to magnetite $\left(\mathrm{Fe}_{3} \mathrm{O}_{4}-\mathrm{L}\right)$ was obtained by the condensation reaction of $\mathrm{Fe}_{3} \mathrm{O}_{4}$-en with diethyl-2,3-O-benzylidene-(+)-tartrate in a 
macrocyclization reaction (Scheme 1). The macrocyclic ligand was metallated with $\mathrm{MnCl}_{2} \cdot 4 \mathrm{H}_{2} \mathrm{O}$ and during the reaction $\mathrm{Mn}$ (II) oxidized to $\mathrm{Mn}(\mathrm{III})$ by air. The macrocyclic ligand $\mathrm{L}$ provides a $\mathrm{N}_{4}$ coordination sphere through two amide- $\mathrm{N}$ and two deprotonated amide- $\mathrm{N}$ ligations to the Mn(III) ion, stabilizing its $3+$ oxidation state in the complex (Scheme 1). The deprotonated secondary amides provide an appropriate ligand field, since these are comparatively strong sdonors, negatively charged, and have proven to be sufficiently oxidation resistant [40].

$<$ Scheme 1 $>$

Recently, a manganese(III) complex of an acyclic amido-amine ligand has been reported by Ramidi et al [41]. It has been also found that when manganese(III) tetraamido-N macrocyclic ligand and related complexes are treated with peroxides the $\mathrm{Mn}(\mathrm{V})$-monooxo complexes were produced [42]. One method to achieve increased stability of the metal complexes is to rigidify the chelator thus slowing down the kinetics of dissociation [43]. This work has mainly been aimed at copper(II) complexes which are often thermodynamically stable but kinetically labile [44]. Tetraazamacrocycles incorporating both amide groups and a backbone benzene ring were synthesized as chelators for copper radionuclides. When deprotonated, the 13-membered macrocycle forms a highly stable copper(II) complex and the ${ }^{67} \mathrm{Cu}$ labelled compound is stable in serum [45].

The FT-IR spectra of $\mathrm{Fe}_{3} \mathrm{O}_{4} @ \mathrm{SiO}_{2}$, the intermediates and $\mathrm{Fe}_{3} \mathrm{O}_{4}-[\mathrm{MnCl}(\mathrm{L})]$ are shown in Fig. 2. The bands at 3429 and $1629 \mathrm{~cm}^{-1}$ are assignable to the $v(\mathrm{O}-\mathrm{H})$ and $\delta(\mathrm{O}-\mathrm{H})$ mode [46] of water molecules, respectively. The amine and amide N-H bending of the compounds appear about $1630 \mathrm{~cm}^{-1}$ which are overlapping with the water O-H bending mode. 
The characteristic antisymmetric $\left(v_{\text {as }}\right) \mathrm{Si}-\mathrm{O}-\mathrm{Si}$ vibration bands [47] of the $\left[\mathrm{SiO}_{4}\right]$ unit is observed around 1218 and $1093 \mathrm{~cm}^{-1}$ for the core-shell $\mathrm{Fe}_{3} \mathrm{O}_{4} @ \mathrm{SiO}_{2}$. The band at $799 \mathrm{~cm}^{-1}$ is assigned to $v_{\mathrm{s}}(\mathrm{Si}-\mathrm{O}-\mathrm{Si})$ mode. Formation of the amino propionate ester $\left(\mathrm{Fe}_{3} \mathrm{O}_{4}-\mathrm{CO}_{2} \mathrm{Me}\right)$ was confirmed by the appearance of the $\mathrm{CO}_{2}$ band at $1736 \mathrm{~cm}^{-1}$. Furthermore, disappearance of the ester $\mathrm{CO}_{2}$ band in intermediate $\mathrm{Fe}_{3} \mathrm{O}_{4}$-en and its appearance in $\mathrm{Fe}_{3} \mathrm{O}_{4}$ - $\mathrm{L}$ at $1745 \mathrm{~cm}^{-1}$ strongly approved the formation of the macrocyclic tetraamide ligand. The bending mode of the amide N-H at 1615 $\mathrm{cm}^{-1}$ was also confirmed the formation of $\mathrm{Fe}_{3} \mathrm{O}_{4}-\mathrm{L}$. The insertion of $\mathrm{Mn}$ into the macrocycle caused a shift in the amide N-H bending mode from 1615 to $1629 \mathrm{~cm}^{-1}$.

$<$ Fig. $2>$

The thermal stability of $\mathrm{Fe}_{3} \mathrm{O}_{4}-\mathrm{L}$ and $\mathrm{Fe}_{3} \mathrm{O}_{4}-[\mathrm{MnCl}(\mathrm{L})]$ nanocomposite were examined by means of TGA and the results are shown in Fig. 3. The nanocomposite containes $6.7 \%$ of organic material which belongs to the PVP adsorbed on the magnetite nanoparticles and immobilized macrocyclic ligand. The organic content for $\mathrm{Fe}_{3} \mathrm{O}_{4}-\mathrm{L}$ was $14.9 \%$. The remarkable parallelism of the two TGA curves confirms the presence of the same organic material. The lower weight loss of the nanocomposite with respect to $\mathrm{Fe}_{3} \mathrm{O}_{4}-\mathrm{L}$ can be due to the formation manganese oxides, probably $\mathrm{Mn}_{3} \mathrm{O}_{4}$, by increasing the temperature up to $570{ }^{\circ} \mathrm{C}$. The content of manganese in $\mathrm{Fe}_{3} \mathrm{O}_{4}-[\mathrm{MnCl}(\mathrm{L})]$ sample was confirmed with measuring $\mathrm{Mn}$ of the sample by ICP analysis $(2.5$ $\mathrm{wt} \%, 0.46 \mathrm{mmol} \mathrm{Mn} / \mathrm{g}$ composite).

$<$ Fig. $3>$

Morphology of the $\mathrm{Fe}_{3} \mathrm{O}_{4}-[\mathrm{MnCl}(\mathrm{L})]$ nanoparticles was examined by SEM (Fig. 4a). The nanocomposite particles have nearly disk shape and uniform size distribution with an average size of $95 \mathrm{~nm}$. The grain sizes of the samples estimated from the SEM picture are larger than those obtained from XRD data. This means that, the SEM picture indicates the size of 
polycrystalline particles. The observation of some larger nanoparticles may be attributed to the fact that $\mathrm{Fe}_{3} \mathrm{O}_{4}-[\mathrm{MnCl}(\mathrm{L})]$ nanoparticles have the tendency to self-agglomeration due to their high surface energy of the fine nanoparticles. The nanoparticles of $\mathrm{Fe}_{3} \mathrm{O}_{4}-[\mathrm{MnCl}(\mathrm{L})]$ are stable and preserve their shape and uniform distribution after catalysis. After four times recycle in the catalytic oxidation of $\alpha$-methylstyrene, the nanoparticles are well separated and their size increased to an average of $118 \mathrm{~nm}$ (Fig. $4 \mathrm{~b}$ and c).

$<$ Fig. $4>$

The magnetic properties of the synthesized $\mathrm{Fe}_{3} \mathrm{O}_{4}-[\mathrm{MnCl}(\mathrm{L})]$ indicated a superparamagnetic nature of the material (Fig. 5). The magnetization value of $\mathrm{Fe}_{3} \mathrm{O}_{4}-[\mathrm{MnCl}(\mathrm{L})]$ $\left(15 \mathrm{emu} \mathrm{g}^{-1}\right)$ is lower than the value of $\mathrm{Fe}_{3} \mathrm{O}_{4}$-tart-NPs $\left(55 \mathrm{emu} \mathrm{g}^{-1}\right)$ but is basically close to other results [48]. On the one hand, this feature allows catalyst separation under relatively low external magnetic field. The negligible coercivity indicates the superparamagnetic property of this sample, which is available for re-dispersion of the catalysts in solution without the occurrence of severe assembly and/ or aggregation usually appearing for ferromagnetic nanoparticles [49]. After removing the magnet from the batch a few minutes later the catalysts were re-dispersed completely as shown before adding the magnet.

$$
<\text { Fig. } 5>
$$

Fig. 6 shows the electron spin resonance (ESR) spectra recorded for the powder of the $\mathrm{Fe}_{3} \mathrm{O}_{4}-[\mathrm{MnCl}(\mathrm{L})]$ composite at room and liquid helium temperatures. The big broad absorption is dominated at all temperatures. The integral intensity of this absorption is barely changed between $300 \mathrm{~K}$ and $10 \mathrm{~K}$, whilst the resonance locus is shifted to the direction of lower magnetic field at lower temperature. The non paramagnetic behavior allow us to assign the resonance absorption in Fig. 6 with ferromagnetic resonance of magnetite nanoparticles. Since it is powder, 
the particles are here randomly orientated with respect to the magnetic field and the spectrum represents the envelope of all resonance lines summed over all possible orientations. The temperature shift toward lower magnetic field of the resonance absorption reflects an increase of magnetic anisotropy of single particles or even inter-particle interactions [50]. Given the ferromagnetic resonance from magnetite is dominant, the open question remains about resonance absorption of manganese. Because of large ZFS splitting, the Mn(III) ions are "silent" in the Xband $(9.3 \mathrm{GHz})$ ESR spectroscopy. The only signal that was expected to be seen is $\mathrm{Mn}(\mathrm{II})$. We do not see this signal, easily detectable in paramagnetic compounds, however strong dipolar interaction with magnetite particles could make $\mathrm{Mn}(\mathrm{II})$ absorption too broad for detection.

$$
<\text { Fig. } 6>
$$

\subsection{Catalytic oxidation}

Having synthesized and characterized $\mathrm{Fe}_{3} \mathrm{O}_{4}-[\mathrm{MnCl}(\mathrm{L})]$ nanocomposite, its role as a heterogeneous catalyst was then evaluated for the oxidation of olefins. We first examined the reaction using the nanocomposite as a catalyst in air oxidation of phenylcyclohexene (Table 1). The oxidation of 1-phenylcyclohexene by aqueous $\mathrm{H}_{2} \mathrm{O}_{2}$ as oxidant was not successful, since $\mathrm{H}_{2} \mathrm{O}_{2}$ was decomposed by $\mathrm{Fe}_{3} \mathrm{O}_{4}-[\mathrm{MnCl}(\mathrm{L})]$ in early minutes of the reaction (Table 1, entry 1). Therefore, molecular $\mathrm{O}_{2}$ was used as a green and economic oxidant in the oxidation reaction. Presence of a co-oxidant such as isobutyraldehyde [51] or other reducing agent $[52,53]$ is essential for the activation of dioxygen. The mixture of $\mathrm{O}_{2} / \mathrm{p}$ prCHO without catalyst showed poor oxidation catalysis (Table 1, entry 2), and using the combination of $\mathrm{O}_{2} / \mathrm{i}$ prCHO and support $\mathrm{Fe}_{3} \mathrm{O}_{4} /$ tart-NPs increased the conversion to $37 \%$ with enantiomeric excess of $62 \%$ (entry 3 ). Interestingly, the nanocomposite was a very efficient catalyst and 
catalyzed the oxidation by $\mathrm{O}_{2} /{ }^{\mathrm{i}} \mathrm{PrCHO}$ with $100 \%$ conversion and $82 \%$ ee within $8 \mathrm{~h}$ (entry 4 ). Co-oxidation of 1-phenylcyclohexene and isobutyraldehyde under the investigated conditions led to the formation of 1-phenylcyclohexene oxide and isobutyric acid. The reaction was performed directly under oxygen atmosphere by using $\mathrm{O}_{2}$ balloon and high pressure of oxygen was not necessary. Both $\mathrm{O}_{2}$-balloon and $\mathrm{O}_{2}$ gas with 2 bar pressure in an autoclave, gave the similar results (Table 1, entry 5); for simplicity $\mathrm{O}_{2}$-balloon was selected. The reaction temperature showed a negative effect on the oxidation. A temperature increase from $25{ }^{\circ} \mathrm{C}$ to 45 or $60{ }^{\circ} \mathrm{C}$ led to a decrease in the conversion and ee (Table 1, entries 6, 7). Probably, the active species is not stable at higher temperatures. Thereby the room temperature was chosen as optimized temperature.

Furthermore, cyclooctene, cyclohexene and tetralin were also examined to explore the scope of the catalytic activity of the nanocomposite (not shown in the Table). Under optimized conditions, the $\mathrm{Fe}_{3} \mathrm{O}_{4}-[\mathrm{MnCl}(\mathrm{L})] / \mathrm{O}_{2} /{ }^{\mathrm{i}} \mathrm{prCHO} / \mathrm{CH}_{3} \mathrm{CN}$ system oxidized cis-cyclooctene to cyclooctene oxide with $100 \%$ conversion and $94 \%$ selectivity within $6 \mathrm{~h}$; cyclohexene to cyclohexene oxide with $100 \%$ conversion and $89 \%$ selectivity within $4 \mathrm{~h}$; tetralin to 1 -tetralol with $43 \%$ yield within $9 \mathrm{~h}$ and benzyl alcohol to benzaldehyde with $66 \%$ yield in $9 \mathrm{~h}$. Tetralin is a convenient substance to choose for studying the autoxidation of the $\mathrm{CH}_{2}$ group [54].

Acetonitrile as solvent provided better medium than methanol, $n$-hexane or ethylacetate. In fact, the catalyst did not work in methanol or $n$-hexane. Although, the oxidation of $\alpha$ methylstyrene in ethylacetate was high (conversion 100\%), epoxide selectivity as low as $60 \%$ with $70 \%$ ee was achieved. However, the activity of the nanocomposite in acetonitrile was remarkable and it could oxidize $\alpha$-methylstyrene quantitatively with $90 \%$ epoxide selectivity and $71 \%$ ee under the same reaction conditions. Acetonitrile did not involve through peroxymidic 
acid, since no $\mathrm{MeCONH}_{2}$ under the catalytic oxidations was detected [55]. These findings suggest that the polarity [56], low coordinating ability and aprotic nature of acetonitrile play the main roles in improving the activity of the catalyst.

\section{$<$ Table $1>$}

Under the optimized conditions, aerobic oxidation of various prochiral olefins was studied. The catalyst $\mathrm{Fe}_{3} \mathrm{O}_{4}-[\mathrm{MnCl}(\mathrm{L})]$ exhibited broad substrate scope and was highly selective toward epoxidation with $\mathrm{O}_{2} /{ }^{j} \mathrm{PrCHO}$. It remarkably catalyzed the epoxidation of linear terminal olefins, cycloolefins and aromatic olefins with excellent selectivity of 87 to $100 \%$, except styrene (Table 2). 1-Decene and 1-octene were oxidized by $\mathrm{Fe}_{3} \mathrm{O}_{4}-[\mathrm{MnCl}(\mathrm{L})] / \mathrm{O}_{2} /{ }^{i} \mathrm{PrCHO}$ with $34 \%$ and $70 \%$ conversions, respectively, and more than $99 \%$ ee (Table 2 , entries 1,3 ).

By increasing the temperature from 25 to $60{ }^{\circ} \mathrm{C}$, the conversion of 1-decene increased from $34 \%$ to $69 \%$ (entry 2). Probably there are different mechanisms for conjugated (1phenylcyclohexene) and unconjugated (1-decene) olefins oxidation by $\mathrm{Fe}_{3} \mathrm{O}_{4^{-}}$ $[\mathrm{MnCl}(\mathrm{L})] / \mathrm{O}_{2} /{ }^{\mathrm{i}} \mathrm{PrCHO} / \mathrm{CH}_{3} \mathrm{CN}$ system. While the oxidation of 1-phenylcyclohexene was decreased by increasing the reaction temperature (Table 1), the oxidation of 1-decene increased (Table 2) by going from 25 to $60^{\circ} \mathrm{C}$.

In addition to the main product of the corresponding epoxides, the oxidation of styrene, $\alpha$ - and $\beta$-methylstyrene were occurred partially by breaking the double bond and benzaldehyde or acetophenone obtained (entries 4-6). The stability of the plausible intermediate benzyl radical favors breaking of the olefin double bond in styrene, $\alpha$ - and $\beta$-methylstyrene. In $\alpha$ - and $\beta$ substituted styrene, presence of the electron donor substituent (methyl) increased the epoxide selectivity with respect to styrene. Enantioselectivity in the oxidation of $\beta$-methyl styrene was the 
highest. These findings show the importance of steric hindrance effect during the oxygen transfer step and electrophilic nature of the active oxygen transfer intermediate.

Catalyst $\mathrm{Fe}_{3} \mathrm{O}_{4}-[\mathrm{MnCl}(\mathrm{L})]$ was also tested for the oxidation of cis- and transstilbene (entries 8,9). cis-Stilbene is a frequently used substrate for the study of olefin epoxidation mechanism [57] because of mechanistic information associated with the ratio of cisand trans-isomers in the stilbene oxide product. Trans-stilbene was oxidized quantitatively to trans-stilbene oxide, but $c i s$-stilbene epoxide (46\%) and thermodynamically stable trans-stilbene oxide (54\%) were obtained by the oxidation of cis-stilbene. This finding also emphasizes on the critical role of steric effect in determining the product selectivity by this catalyst. The oxidation reaction probably proceeds through a benzyl radical intermediate, which allows free rotation about the $\mathrm{C}-\mathrm{C}$ bond axis. In addition, our preliminary experiments in the presence of hydroquinone as a radical scavenger proved the involvement of a radical intermediate in the oxidation of styrene by $\mathrm{Fe}_{3} \mathrm{O}_{4}-[\mathrm{MnCl}(\mathrm{L})] / \mathrm{O}_{2} / \mathrm{PrCHO} / \mathrm{CH}_{3} \mathrm{CN}$ system.

Indene was oxidized by $\mathrm{O}_{2} /$ isobutyraldehyde in the presence of $\mathrm{Fe}_{3} \mathrm{O}_{4}-[\mathrm{MnCl}(\mathrm{L})]$ to indene oxide with $100 \%$ selectivity and $53 \%$ ee in $9 \mathrm{~h}$ (entry 10). Epoxidation of indene usually leads to the formation of various products but the selectivity to one of the products, viz., the epoxide is of great importance for the chemical industry [58].

The enantioselectivity of the present $\mathrm{Fe}_{3} \mathrm{O}_{4}-[\mathrm{MnCl}(\mathrm{L})]$ catalyst are comparable and sometimes better than chiral Mn complexes with complicated and difficult to synthesis $\mathrm{N}_{4}$ macrocylic ligands in the oxidation of styrene with $\mathrm{H}_{2} \mathrm{O}_{2}[59,60,61,62,63]$.

$<$ Table 2> 


\subsection{Recyclability study}

The catalyst $\mathrm{Fe}_{3} \mathrm{O}_{4}-[\mathrm{MnCl}(\mathrm{L})]$ was tested for its reusability in the epoxidation of $\alpha$-methylstyrene with $\mathrm{O}_{2}$ /aldehyde as an oxidant under the optimized reaction conditions. After the first catalytic run, the catalyst was separated from the reaction mixture using an external magnet and the residue was washed with acetonitrile to remove the product, dried at $80^{\circ} \mathrm{C}$ for $1 \mathrm{~h}$, and used as such for the subsequent catalytic runs without further purification (Fig. 7). The FT-IR spectra (Fig. S3) and SEM images (Fig. 4) of the initial catalyst and the recycled catalyst showed the integrity of the catalyst after three catalytic cycles. Total TON of 16957 was obtained after four cycles. The activity of the catalyst decreased after 4 times use because of the complex degradation.

Although the conversion was almost constant during the experiments, but selectivity to acetphenone was increased and the selectivity to $\alpha$-methylstyrene oxide decreased with each recycling step. These findings may be related to the adsorption of moisture by the catalyst. The nanocomposite is highly hygroscopic and this property is clearly seen in its TGA spectrum (Fig. 3). Drying of the used catalyst before each experiments slightly improved its activity, however its selectivity was lower than that of the fresh one yet.

$<$ Fig. $7>$

\subsection{Possible Mechanism}

The key role of $\mathrm{Fe}_{3} \mathrm{O}_{4}-[\mathrm{MnCl}(\mathrm{L})]$ catalyst is evident in the oxidation of olefins. In the absence of catalyst almost no reaction occurred under our mild operating conditions with $\mathrm{O}_{2}$ /aldehyde (Table 1, entry 2). It showed high catalytic activity and selectivity for the epoxidation of various 
olefins by molecular oxygen/aldehyde. Additionally, cyclohexene was oxidized mainly to cyclohexene oxide ( $89 \%)$ by this system. It has often been assumed that high-valent metal oxo species are the most likely active intermediates when olefins are selectively oxidized to the corresponding epoxides in metal complex-catalyzed oxygen atom transfer reactions $[64,65]$.

Additional evidence for this was obtained from stereochemical investigations of the epoxidation of cis/trans stilbene. Cis-Stilbene was converted to cis- and trans-epoxide almost with $50 \%$ retention of configuration. Furthermore, electron-rich $\alpha$ - and $\beta$-substituted styrene with the electron donor substituent (methyl) increased the epoxide selectivity with respect to styrene. These reflect the electrophilic nature of the oxygen transfer from the plausible intermediate to the olefin. Enantioselectivity in the oxidation of $\beta$-methyl styrene was the higher than $\alpha$-isomer. It shows the importance of steric hindrance effect during the oxygen transfer step.

Although suggesting a mechanism required further detailed studies in future, we suppose that the oxygenation of substrates with $\mathrm{Fe}_{3} \mathrm{O}_{4}-[\mathrm{MnCl}(\mathrm{L})]$ and $\mathrm{O}_{2}$ /aldehyde occurs by a mechanism proposed to the oxidation with $\mathrm{O}_{2} /$ aldehydes catalyzed by metal complexes as is given in Scheme 2 [66]. In this mechanism, the supported Mn-macrocycle complex ([Mn $\left.{ }^{\mathrm{III}}\right]$ ) reacts with the aldehyde to generate an acyl radical $\left(\mathrm{RC}(\mathrm{O})^{\circ}\right)$. The acyl radical then reacts with dioxygen to give an acylperoxy radical $\left(\mathrm{RC}(\mathrm{O}) \mathrm{OO}^{\circ}\right)$. The acylperoxy radical acts as a carrier in a chain mechanism by reacting with another aldehyde molecule to give the peroxyacid, thereby generating another acyl radical. Oxygenation of substrate is assumed by this mechanism to occur via a reactive high-valent $\mathrm{Mn}$-oxo intermediate, which is produced by the reaction of the peroxyacid with the $\mathrm{Mn}-\mathrm{L}$ of $\mathrm{Fe}_{3} \mathrm{O}_{4}-[\mathrm{MnCl}(\mathrm{L})]$ and which then reacts with the substrate (olefin) to give the oxygenated product. The induction time of about $4 \mathrm{~h}$ in the oxidation of 1- 
phenylcyclohexene can be considered the required time for the formation of acylperoxy radical and/or Mn-oxo active intermediate (Fig. 8).

$<$ Scheme 2>

$<$ Fig. 8>

\section{Conclusions}

A novel tetraamide macrocyclic ligand complex of $\mathrm{Mn}(\mathrm{III})$ was synthesized onto magnetite and applied in the catalytic epoxidation of various olefins with $\mathrm{O}_{2} /$ aldehyde. To the best of our knowledge, this is the first report on the chiral tetramide macrocyle complex of the manganese catalyzed asymmetric aerobic oxidation, allowing for general epoxidation of a relatively wide variety of olefins in good yield and ee values up to greater than $99 \%$. Moreover, the synthesized nanocatalyst can be recovered by simple magnetic decantation. In addition, the heterogeneous nanocatalysts are relatively stable and can be reused four times

\section{Acknowledgments}

We are grateful for financial support from the University of Zanjan and the Iran National Science Foundation (INSF 95820950) and Polish Academy of Sciences (PAN) for financial support of this study.

\section{References}


[1] G. D. Faveri, G. Ilyashenko, M. Watkinson, Chem. Soc. Rev. 40 (2011) 1722.

[2] W. Dai, G. Li, B. Chen, L. Wang, S. Gao, Org. Lett. 17 (2015) 904.

[3] P. McMorn, G. J. Hutchings, Chem. Soc. Rev. 33 (2004) 108.

[4] D. Sinou, Adv. Synth. Catal. 344 (2002) 221.

[5] R. V. Ottenbacher, D. G. Samsonenko, E. P. Talsi, K. P. Bryliakov, ACS Catal. 4 (2014) 1599.

[6] H. Hasan, Manganese, The Rosen Publishing Group, New York, 2008

[7] K. Barnese, E.B. Gralla, J. S. Valentine, D.E. Cabelli, Proc. Natl. Acad. Sci. U. S. A. 109 (2012) 6892.

[8] D.A. Valyaev, G. Lavigne, N. Lugan, Coord. Chem. Rev. 308 (2016) 191.

[9] X.B. Cheng, R. Jia, P.S. Li, S.Q. Tu, Q. Zhu, W.Z. Tang, X.D. Li, Enzyme Microb. Technol. 41 (2007) 258.

[10] L. Dubois, J. Pecaut, M.-F. Charlot, C. Baffert, M.-N. Collomb, A. Deronzier, J.-M. Latour, Chem.-Eur. J. 14 (2008) 3013.

[11] S. Mukhopadhyay, S.K. Mandal, S. Bhaduri, W.H. Armstrong, Chem. Rev. 104 (2004) 3981.

[12] K. Wieghardt, Angew. Chem., Int. Ed. Engl. 33 (1995) 725.

[13] S.A. Zarei, A. Khandar, M. Khatamian, S.A. Hosseini-Yazdi, I. Dechamps, E. Guillon, M. Piltan, Inorg. Chim. Acta 394 (2013) 348.

[14] N.E. Borisova, M.D. Reshetova, Y.A. Ustynyuk, Chem. Rev. 107 (2006) 46.

[15] R.E. Mewis, S.J. Archibald, Coord. Chem. Rev. 254 (2010) 1686. 
[16] S. Chandra, K. Gupta, Transit. Met. Chem. 27(2002) 196.

[17] S.K. Gupta, Y.S. Kushwah, Polyhedron 20 (2001) 2019.

[18] H. Hosseini-Monfared, V. Aghapoor, M. Ghorbanloo, P. Mayer, Appl. Catal. A 372 (2010) 209.

[19] M.J.F. Calvete, M. Silva, M.M. Pereira, H.D. Burrows, RSC Adv. 3 (2013) 22774.

[20] I. a rcia- osch, . me z, A. Polo, X. Ribas, M. Costas, Adv. Synth. Catal. 354 (2012) 65.

[21] S. Sengupta, C. Panda, M. Ghosh, US8754206 B2.

[22] N.Ch. Maity, P.K. Bera, D. Ghosh, S.H.R. Abdi, R.I. Kureshy, N.H. Khan, H.C. Bajajab, E. Suresh, Catal. Sci. Technol. 4 (2014) 208.

[23] C.W. Yeh, K.H. Chang, C.Y. Hu, W. Hsu, J.D. Chen, Polyhedron 31 (2012) 657.

[24] A.K. Sharma, S. Biswas, S.K. Barman, R. Mukherjee, Inorg. Chim. Acta 363 (2010) 2720.

[25] A. Chanda, D.-L. Popescu, F.T. de Oliveira, E.L. Bominaar, A.D. Ryabov, E. Munck, T.J. Collins, J. Inorg. Biochem. 100 (2006) 606.

[26] L.M. Rossi, N.J.S. Costa, F.P. Silva, R. Wojcieszak, Green Chem. 16 (2014) 2906.

[27] R. Mr wczyński, A. Nan, J. Liebscher, RSC Adv. 4 (2014) 5927.

[28] V. Polshettiwar, R. Luque, A. Fihri, H. Zhu, M. Bouhrara, J.M. Basset, Chem. Rev. $111(2011) 3036$.

[29] J. Sun, G. Yu, L. Liu, Z. Li, Q. Kan, Q. Huo, J. Guan, Catal. Sci. Technol. 4 (2014) 1246.

[30] S. Alavi, H. Hosseini-Monfared, P. Aleshkevych, RSC Adv. 4 (2014) 48827.

[31] L. Hadian-Dehkordi, H. Hosseini-Monfared, Green Chem. 18 (2016) 497. 
[32] T. Yoon, J.S. Kim, B.G. Kim, K.N. Yu, M. Cho, J. Lee, Angew. Chem. Int. Ed. 44 (2005) 1068.

[33] R. Abu-Reziq, H. Alper, D. Wang, M.L. Post, J. Am. Chem. Soc. 128 (2006) 5279.

[34] S. Ghosh, A.K. Banthia, B.G. Maiya, J. Am. Chem. Soc. 4 (2002) 3603.

[35] M. Ghorbanloo, H. Hosseini-Monfared, C. Janiak, J. Mol. Cat. A 345 (2011) 12.

[36] C. Graf, D.L.J. Vossen, A. Imhof, A. van Blaaderen, Langmuir 19 (2003) 6693.

[37] S. Hecht, J.M.J. Frechet, Angew. Chem. Int. Ed. 40 (2001) 75.

[38] D. Astruc, F. Chardac, Chem. Rev. 101 (2001) 2991.

[39] N. Tsubokawa, H. Ichioka, T. Satoh, S. Hayashi, K. Fujiki, React. Funct. Polym. 37 ( 1998) 75 .

[40] T.J. Collins, Acc. Chem. Res. 35 (2002) 782.

[41] P. Ramidi, C.M. Felton, B.P. Subedi, H. Zhou, Z.R. Tian, Y. Gartia, B.S. Pierce, A. nGhosh, J. $\mathrm{CO}_{2}$ Util. 9 (2015) 48.

[42] T.J. Collins, S.W. Gordon-Wylie, J. Am. Chem. Soc. 111 (1989) 4511.

[43] E. Faggi, R. Gavara, M. Bolte, L. Fajarí, L. Juliá, L. Rodríguez, I. Alfonso, Dalton Trans. $44(2015) 12700$.

[44] T.J. Wadas, E.H. Wong, G.R. Weisman, C.J. Anderson, Curr. Pharm. Des. 13 (2007) 3.

[45] P. Antunes, R. Delgado, M.G.B. Drew, V. Felix, H. Maecke, Inorg. Chem. 46 (2007) 3144.

[46] T. Rajh, L.X. Chen, K. Lukas, T. Liu, M.C. Thurnauer, D.M. Tiede, J. Phys. Chem. B 106 (2002) 10543.

[47] A. Jitianu, M. Crisan, A. Meghea, I. Rau, M. Zaharescu, J. Mater. Chem. 12 (2002) 1401. 
[48] S.F. Si, C.H. Li, X. Wang, D.P. Yu, Q. Peng, Y.D. Li, Cryst. Growth Des. 5 (2005) 391.

[49] C.T. Yavuz, J.T. Mayo, W.W. Yu, A. Prakash, J.C. Falkner, S. Yean, L. Cong, H.J. Shipley, A. Kan, M. Tomson, D. Natelson, V. L. Colvin, Science 314 (2006) 964.

[50] N. Guskos, E.A. Anagnostakis, A. Guskos, J. of Achievements in Materials and Manufacturing Engineering 24 (2007) 26.

[51] R.A. Sheldon, A history of oxygen activation: 1773-1993, in The activation of dioxygen and homogeneous catalytic oxidation, ed. D.H. Barton, A.E. Martell, D.T. Sawyer, Plenum Press, New York, 1993, p. 11.

[52] T. Mukaiyama, T. Yamada, Bull. Chem. Soc. Jpn. 68 (1995) 17.

[53] I. Tabushi, N. Koga, J. Am. Chem. Soc. 101 (1979) 6456.

[54] H. Hock, W. Susemihl, Ber. 66 (1933) 61.

[55] G.B. Payne, P.H. Deming, P.H. Williams, J. Org. Chem. 26 (1961) 659.

[56] V. Gutmann, Coord. Chem. Rev. 18 (1976) 225.

[57] W. Adam, K.J. Roschmann, C.R. Saha-Möller, D. Seebach, J. Am. Chem. Soc. $124(2002) 5068$.

[58] V. Ramaswamya, P. Awatia, A.V. Ramaswamy, Top. Catal. 38 (2006) 251.

[59] F. Bruyneel, C. Letondor, B. Basturk, A. Gualandi, A. Pordea, H. Stoeckli-Evans, R. Neier, Adv. Synth. Catal. 354 (2012) 428.

[60] M. Wu, B. Wang, S. Wang, C. Xia, W. Sun, Org. Lett. 11 (2009) 3622.

[61] J. Rich, M. Rodriguez, I. Romero, X. Fontrodona, W. N. M. Piet, V. Leeuwen, Z. Freixa, X. Sala, A. Poater, M. Sola, Eur. J. Inorg. Chem. (2013) 1213.

[62] N.C. Maity, P.K. Bera, D. Ghosh, S.H.R. Abdi, R.I. Kureshy, N.-U. H. Khan, H.C. Bajaj, E. Suresh, Catal. Sci. Technol. 4 (2014) 208. 
[63] I. Garcia-Bosch, L. Gomez, A. Polo, X. Ribas, Adv. Synth. Catal. 354 (2012) 65.

[64] N.S. Finney, P.J. Pospisil, S. Chang, M. Palucki, R. G. Konsler, K.B. Hansen, E.N.

Jacobsen, Angew. Chem. Int. Ed. Engl. 36 (1997) 1720.

[65] J.T. Groves, J. Lee, S.S. Marla, J. Am. Chem. Soc. 119 (1997) 6269.

[66] L.I. Simandi, Ed., Catalytic Activation of Dioxygen by Metal Complexes, Kluwer Academic Publishers: Dordrecht, The Netherlands, 1992.

\section{Fig/Scheme captions}

Fig. $1 \mathrm{XRD}$ patterns of the synthesized (a) $\mathrm{Fe}_{3} \mathrm{O}_{4} / \operatorname{tart}-\mathrm{NPs}$ and (b) $\mathrm{Fe}_{3} \mathrm{O}_{4}-[\mathrm{MnCl}(\mathrm{L})]$

Scheme 1 The synthesis of $\mathrm{Fe}_{3} \mathrm{O}_{4}-[\mathrm{MnCl}(\mathrm{L})]$

Fig. 2 FT-IR spectra of the synthesized nanocomposite and the support.

Fig. 3 TGA analyses of the synthesized $\mathrm{Fe}_{3} \mathrm{O}_{4}-\mathrm{L}$ and $\mathrm{Fe}_{3} \mathrm{O}_{4}-[\mathrm{MnCl}(\mathrm{L})]$

Fig. 4 SEM images of (a) $\mathrm{Fe}_{3} \mathrm{O}_{4}-[\mathrm{MnCl}(\mathrm{L})]$ as-synthesized, (b) and (c) recovered $\mathrm{Fe}_{3} \mathrm{O}_{4}$ $[\mathrm{MnCl}(\mathrm{L})]$ after 4 times use as catalyst in the oxidation of $\alpha$-methylstyrene with $\mathrm{O}_{2}$ (see the next section). 
Fig. 5 Magnetization curve of (a) $\mathrm{Fe}_{3} \mathrm{O}_{4} /$ tart and (b) $\mathrm{Fe}_{3} \mathrm{O}_{4}-[\mathrm{MnCl}(\mathrm{L})]$. The inset shows photograph of the separation of the dispersed catalyst $\mathrm{Fe}_{3} \mathrm{O}_{4}-[\mathrm{MnCl}(\mathrm{L})]$ in acetonitrile (left) by using an external magnet (right).

Fig. 6 EPR spectra for powdered $\mathrm{Fe}_{3} \mathrm{O}_{4}-[\mathrm{MnCl}(\mathrm{L})]$ complex, recorded at room and liquid helium temperatures.

Fig. 7 Reuse of the catalyst in the aerobic oxidation of $\alpha$-methylstyrene. Conditions as given in the footnote of Table 2. SO, $\alpha$-methylstyrene oxide; BA, benzaldehyde; AP, acetophenone. The epoxide configuration was S. Total TON for four cycle was 16957.

Fig. 8 Kinetic plot for the oxidation of 1-phenylcyclohexene by the nanocomposite under the conditions given in Experimental.

Table 1 Oxidation of 1-phenylcyclohexene ${ }^{\mathrm{a}}$

Table 2 Asymmetric oxidation of unfunctionalized olefins catalyzed by $\mathrm{Fe}_{3} \mathrm{O}_{4}-[\mathrm{MnCl}(\mathrm{L})]^{\mathrm{a}}$ 


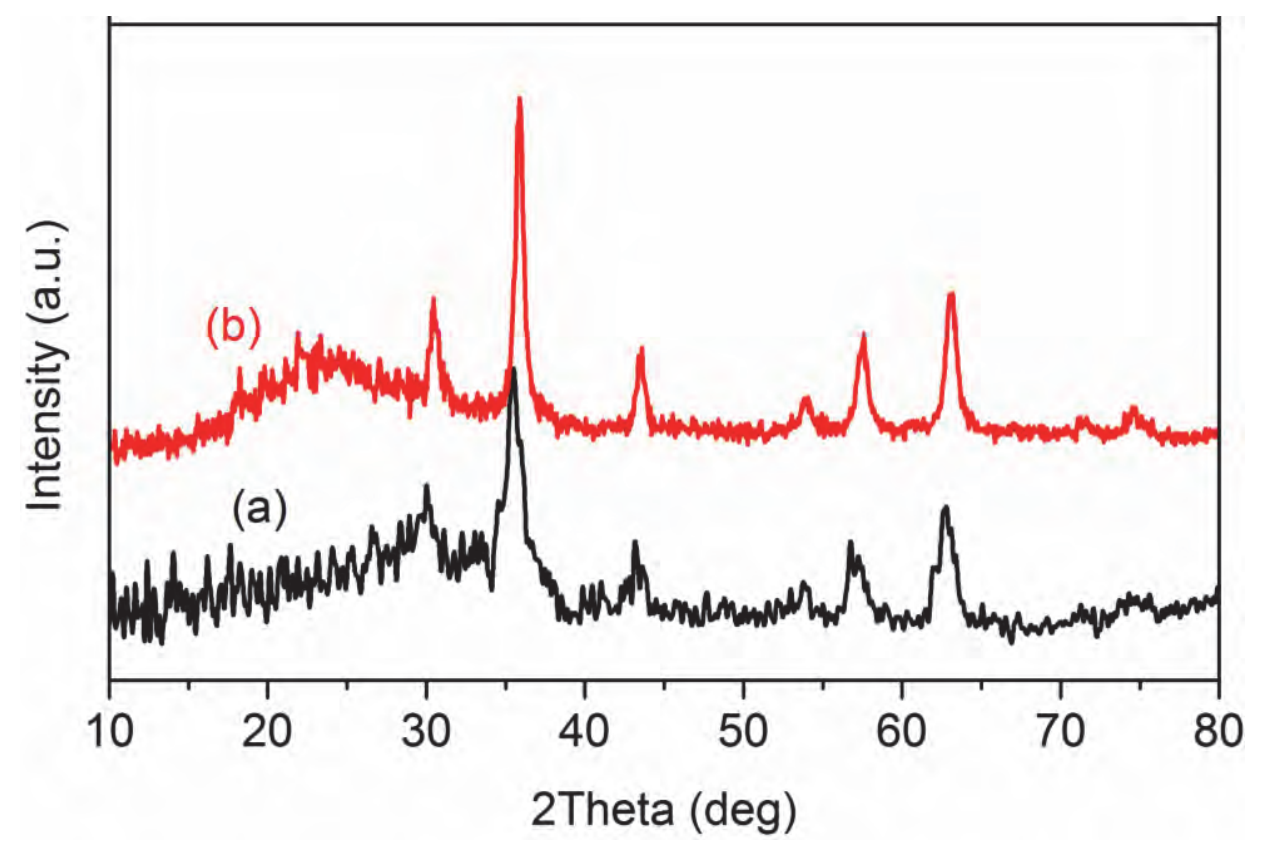

Fig. 1 


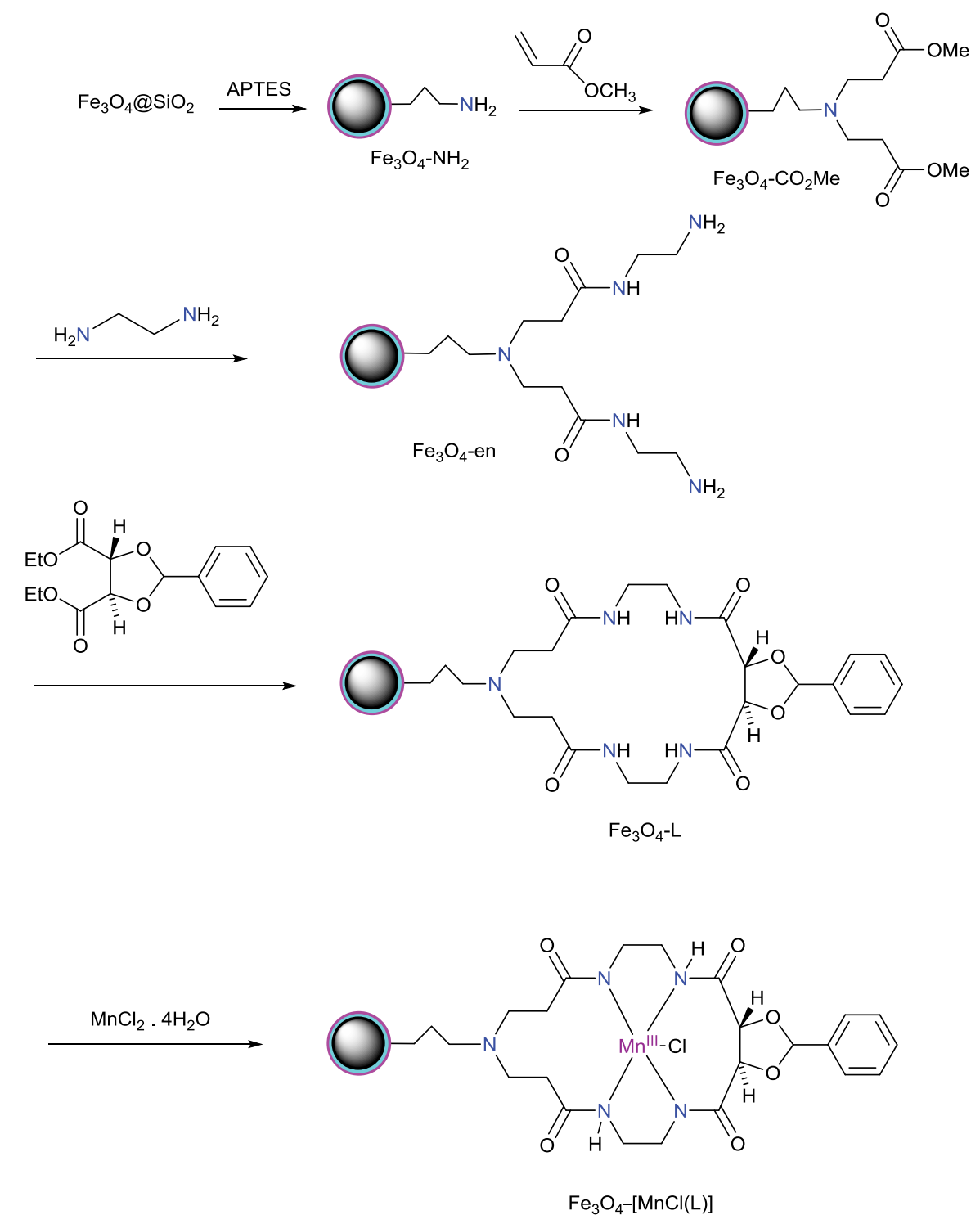

Scheme 1 


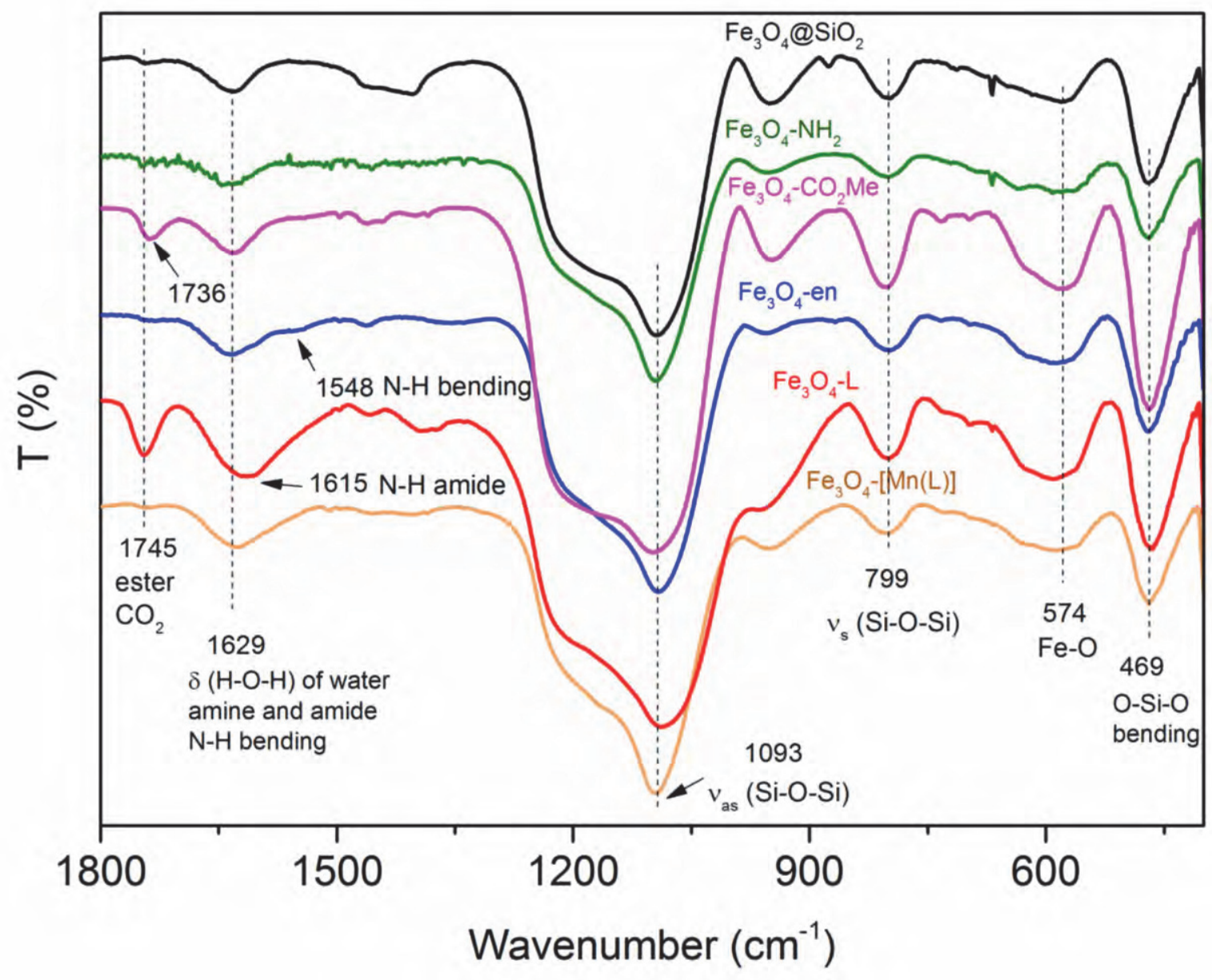

Fig. 2 


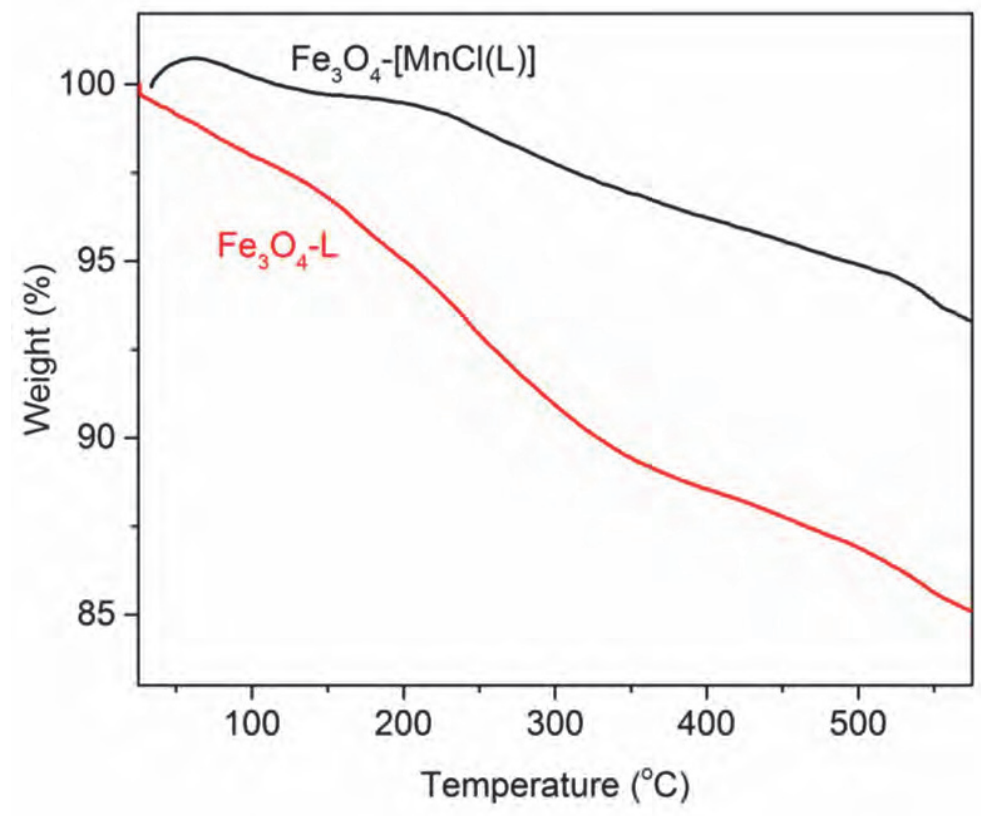

Fig. 3 

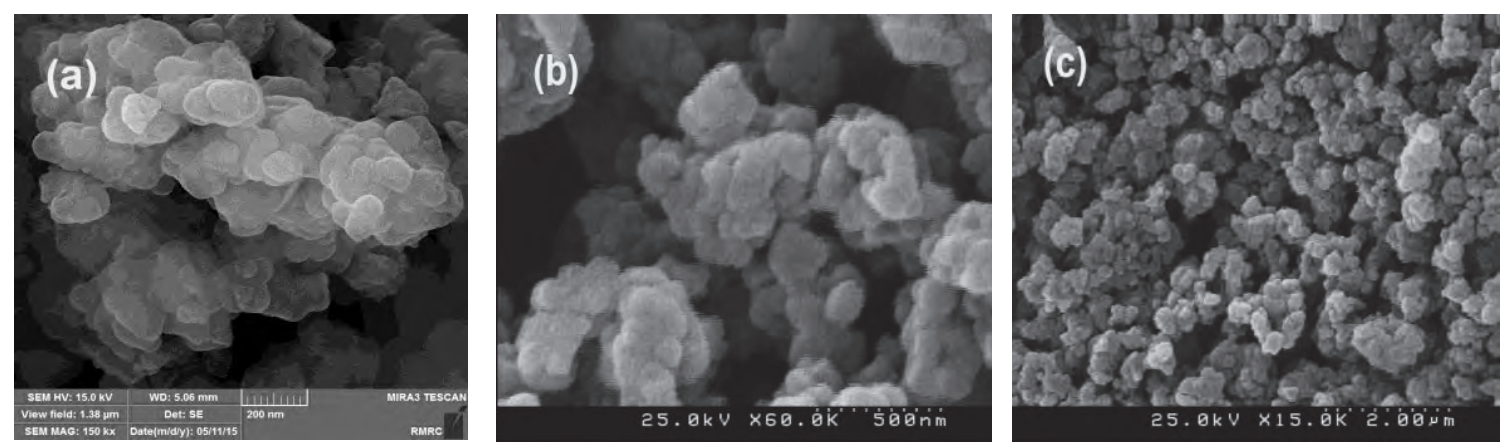

Fig. 4 


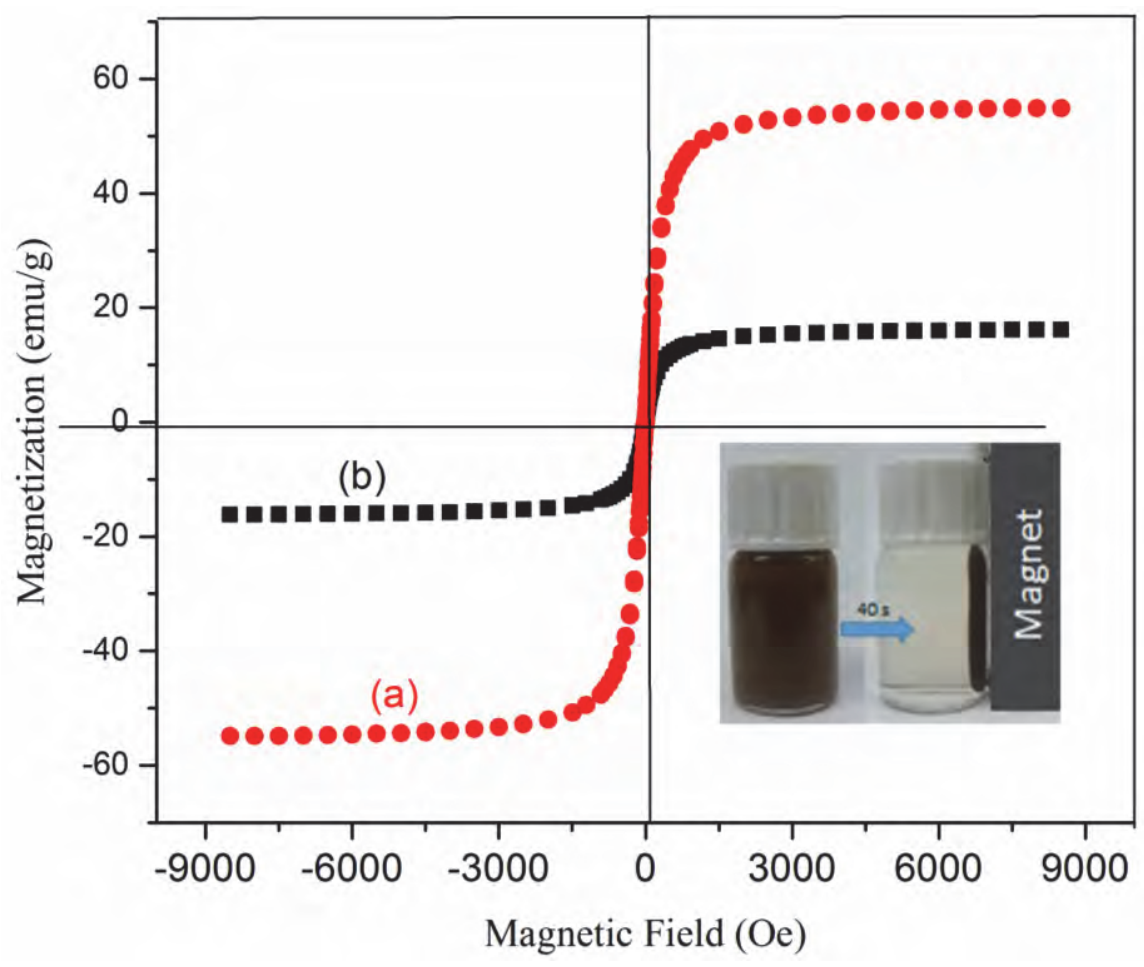

Fig. 5 


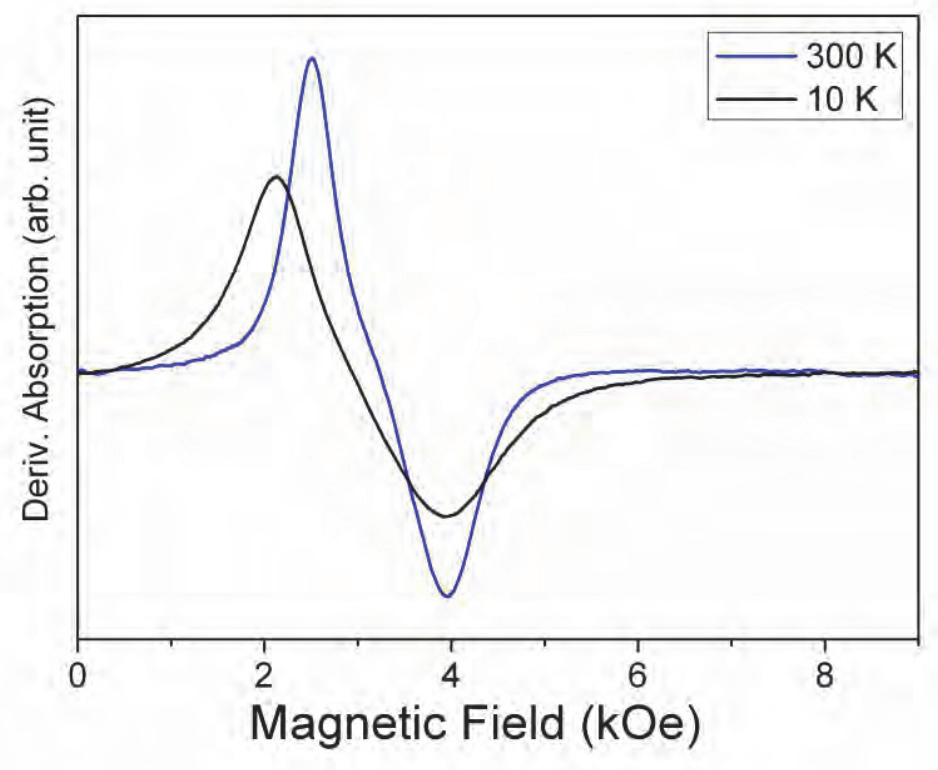

Fig. 6 


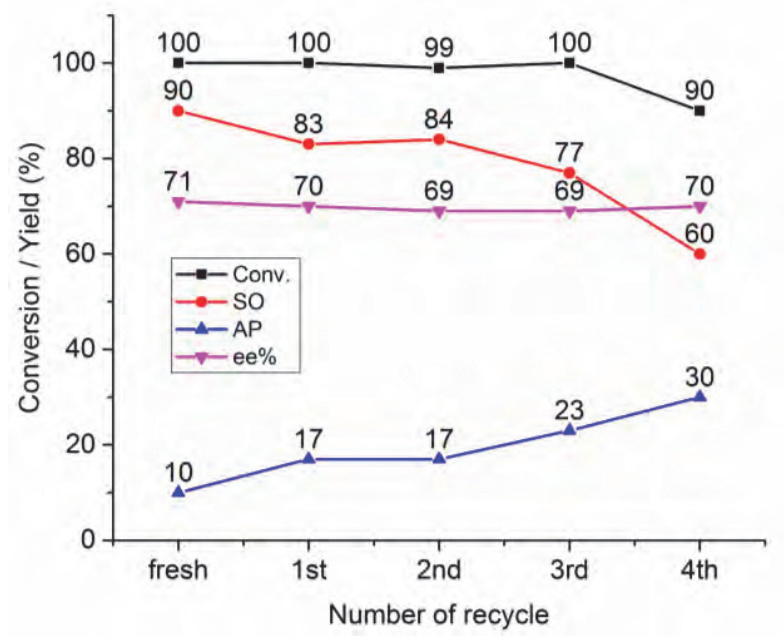

Fig. 7 


$$
\begin{array}{rll}
{\left[\mathrm{Mn}^{\prime \prime \prime}\right]+\mathrm{RCHO}} & \longrightarrow & {\left[\mathrm{Mn}^{\prime \prime}\right]+\mathrm{RC} \mathrm{O}+\mathrm{H}^{+}} \\
\mathrm{RCO}+\mathrm{O}_{2} & \longrightarrow & \mathrm{RCO}_{3}^{\circ} \\
\mathrm{RCO}_{3}+\mathrm{RCHO} & \longrightarrow & \mathrm{RCO}_{3} \mathrm{H}+\mathrm{RCOO} \\
{\left[\mathrm{Mn}^{\prime \prime \prime}\right]+\mathrm{RCO}_{3} \mathrm{H}} & \longrightarrow & {\left[\mathrm{Mn}^{\prime}=\mathrm{O}\right]+\mathrm{RCO}_{2} \mathrm{H}} \\
{\left[\mathrm{Mn}^{\mathrm{V}}=\mathrm{O}\right]+\text { Substrate }} & \longrightarrow & {\left[\mathrm{Mn}^{\prime \prime \prime}\right]+\operatorname{Product}(\mathrm{O})}
\end{array}
$$

\section{Scheme 2}




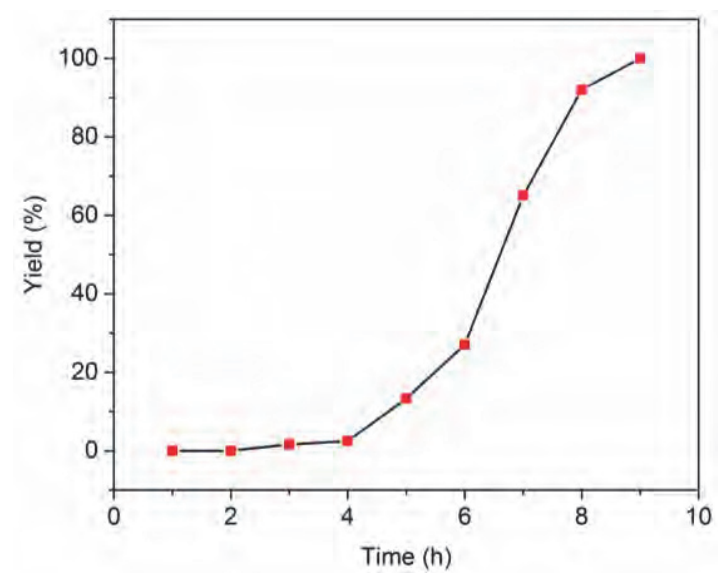

Fig. 8 
Table 1 Oxidation of 1-phenylcyclohexene ${ }^{\mathrm{a}}$

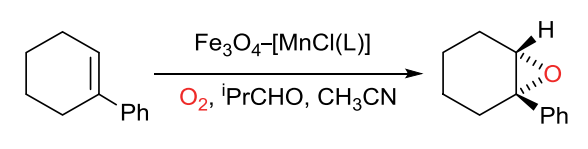

\begin{tabular}{|l|l|l|l|l|l|}
\hline Entry & Catalyst & Temp. & $\begin{array}{l}\text { Conv. } \\
(\%)\end{array}$ & Epoxide & Ee (\%) \\
& & $\left({ }^{\circ} \mathrm{C}\right)$ & & \\
\hline 1 & $\mathrm{Fe}_{3} \mathrm{O}_{4}-[\mathrm{MnCl}(\mathrm{L})] / \mathrm{H}_{2} \mathrm{O}_{2}$ & 25 & 0 & 0 & \\
\hline 2 & $\mathrm{O}_{2} /{ }^{\mathrm{i}} \mathrm{PrCHO}$ & 25 & 0.3 & 0.3 & \\
\hline 3 & $\mathrm{Fe}_{3} \mathrm{O}_{4} / \mathrm{tart}-\mathrm{NPs} / \mathrm{O}_{2} /{ }^{\mathrm{i}} \mathrm{PrCHO}$ & 25 & 37 & $30(\mathrm{R})$ & $62(\mathrm{R})$ \\
\hline 4 & $\mathrm{Fe}_{3} \mathrm{O}_{4}-[\mathrm{MnCl}(\mathrm{L})] / \mathrm{O}_{2} /{ }^{\mathrm{i}} \mathrm{PrCHO}$ & 25 & 100 & $\begin{array}{l}91(\mathrm{~S}) \\
9(\mathrm{R})\end{array}$ & $82(\mathrm{~S})$ \\
\hline 5 & $\mathrm{Fe}_{3} \mathrm{O}_{4}-[\mathrm{MnCl}(\mathrm{L})] / \mathrm{O}_{2} /{ }^{\mathrm{i}} \mathrm{PrCHO}{ }^{\mathrm{c}}$ & 25 & 100 & $\begin{array}{l}91(\mathrm{~S}) \\
9(\mathrm{R})\end{array}$ & $82(\mathrm{~S})$ \\
\hline 6 & $\mathrm{Fe}_{3} \mathrm{O}_{4}-[\mathrm{MnCl}(\mathrm{L})] / \mathrm{O}_{2} /{ }^{\mathrm{i}} \mathrm{PrCHO}$ & 45 & 94 & $\begin{array}{l}82) \mathrm{S}( \\
11) \mathrm{R}(\end{array}$ & $71(\mathrm{~S})$ \\
\hline 7 & $\mathrm{Fe}_{3} \mathrm{O}_{4}-[\mathrm{MnCl}(\mathrm{L})] / \mathrm{O}_{2} /{ }^{\mathrm{i}} \mathrm{PrCHO}$ & 60 & 91 & $\begin{array}{l}66) \mathrm{S}( \\
25) \mathrm{R}(\end{array}$ & $45(\mathrm{~S})$ \\
\hline
\end{tabular}

${ }^{\mathrm{a}} \mathrm{Fe}_{3} \mathrm{O}_{4}-[\mathrm{MnCl}(\mathrm{L})] 1.0 \mathrm{mg}$, isobutyraldehyde $5 \mathrm{mmol}$, 1-phenylcyclohexene $2 \mathrm{mmol}, \mathrm{CH}_{3} \mathrm{CN} 3$

$\mathrm{ml}, \mathrm{O}_{2} 1 \mathrm{~atm}$ and time $9 \mathrm{~h}$.

${ }^{\mathrm{b}}$ Conversions and yields are based the starting material and were determined by GC and is an average of at least two runs.

${ }^{\mathrm{c}}$ The reaction was carried out in the glass inlay of a steel autoclave and $\mathrm{O}_{2}$ pressure was 2 bar. 
Table 2 Asymmetric oxidation of unfunctionalized olefins catalyzed by $\mathrm{Fe}_{3} \mathrm{O}_{4}-[\mathrm{MnCl}(\mathrm{L})]^{\mathrm{a}}$

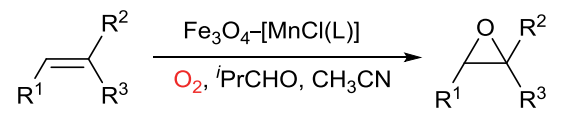

\begin{tabular}{|c|c|c|c|c|c|c|c|c|}
\hline Entry & Substrate & $\begin{array}{l}\text { conv. }^{b} \\
(\%)\end{array}$ & $\begin{array}{l}\text { Product(s), } \\
\text { Yield }(\%){ }^{b}\end{array}$ & $\begin{array}{l}\text { Epoxide } \\
\text { Selectivity } \\
(\%)\end{array}$ & $\begin{array}{l}\text { Ee }(\%)^{c} \\
\text { (Config.) }\end{array}$ & $\begin{array}{l}\text { Time } \\
\text { (h) }\end{array}$ & $\mathrm{TON}^{\mathrm{f}}$ & $\begin{array}{l}\text { TOF } \\
\left(\mathrm{h}^{-1}\right)^{\mathrm{f}}\end{array}$ \\
\hline 1 & & 34 & Epoxide, 34 & 100 & $99(\mathrm{~S})$ & 8 & 1478 & 185 \\
\hline 2 & & $69^{d}$ & Epoxide, 69 & 100 & $99(\mathrm{~S})$ & 8 & 3000 & 375 \\
\hline 3 & & 70 & Epoxide, 70 & 100 & $99(\mathrm{~S})$ & 8 & 3043 & 380 \\
\hline 4 & & 100 & $\begin{array}{l}\text { Benzaldehyde, } 47 \\
\text { R-epoxide, } 41 \\
\text { S-epoxide, } 13\end{array}$ & 44 & $52(\mathrm{~S})$ & 4 & 4348 & 1087 \\
\hline 5 & & 100 & $\begin{array}{l}\text { Acetophenone, } 10 \\
\text { Epoxide, } 90\end{array}$ & 90 & $71(\mathrm{~S})$ & 4 & 4348 & 1087 \\
\hline 6 & & 100 & $\begin{array}{l}\text { Benzaldehyde, } 13 \\
\text { R-epoxide, } 9 \\
\text { S-epoxide, } 78\end{array}$ & 87 & $79(\mathrm{~S})$ & 8 & 4348 & 544 \\
\hline 7 & & 100 & $\begin{array}{l}\text { R-epoxide, } 9 \\
\text { S-epoxide, } 91\end{array}$ & 100 & $82(\mathrm{~S})$ & 9 & 4348 & 483 \\
\hline 8 & & $100^{\mathrm{e}}$ & $\begin{array}{l}\text { Trans-epoxide, } 54 \\
\text { Cis-epoxide, } 46\end{array}$ & 100 & $\mathrm{Nd}^{\mathrm{f}}$ & 8 & 1087 & 136 \\
\hline 9 & & $100^{\mathrm{e}}$ & $\begin{array}{l}\text { Trans-epoxide, } \\
100\end{array}$ & 100 & $\mathrm{Nd}^{\mathrm{f}}$ & 8 & 1087 & 136 \\
\hline 10 & & 47 & Epoxide, 47 & 100 & $53(\mathrm{~S})$ & 9 & 2043 & 227 \\
\hline
\end{tabular}

${ }^{\mathrm{a}}$ Reactions were carried out in $3.0 \mathrm{~mL}$ of $\mathrm{CH}_{3} \mathrm{CN}$ under $\mathrm{O}_{2}$ balloon at room temperature with $\mathrm{Fe}_{3} \mathrm{O}_{4}-[\mathrm{MnCl}(\mathrm{L})] 1.0 \mathrm{mg}(0.46 \mathrm{mmol} \mathrm{Mn} / \mathrm{g}$ composite), isobutyraldehyde $5 \mathrm{mmol}$, substrate 2 mmol. ${ }^{\mathrm{b}}$ Conversions and yields were determined by GC and are an average of at least two runs. ${ }^{\mathrm{c}}$ The enantiomeric excess (ee) values were determined by GC analysis on a chiral stationary phase and every products were identified with ${ }^{1} \mathrm{H}-\mathrm{NMR} .{ }^{\mathrm{d}}$ Reaction temperature $60{ }^{\circ} \mathrm{C} .{ }^{\mathrm{f}} \mathrm{Nd}=$ not determined. ${ }^{\mathrm{e}}$ Substrate $0.5 \mathrm{mmol}$. 
${ }^{\mathrm{f}}$ TON (turnover number) $=$. Total number of moles product $/$ mole catalyst. TOF (turnover frequency) $=$ TON/time 